\title{
A Credit Risk Analysis of Banks: The Users of Credit Cards Influences Financial and Operational Risk in Banks Leading to Credit Risk
}

\author{
R. Shenbagavalli ${ }^{1}$, V. M. Ponniah ${ }^{1}$, S. Senthilkumar ${ }^{2} \&$ P. Abirami ${ }^{3}$ \\ ${ }^{1}$ SRM University, Tamilnadu, India \\ ${ }^{2}$ Asan Memorial College of Arts \& Science, Tamilnadu, India \\ ${ }^{3}$ M.N.M Jain Engineering College, Tamilnadu, India \\ Correspondence: R. Shenbagavalli, SRM University, Tamilnadu, India. E-mail: rsvphd2009@gmail.com
}

Received: August 24, 2014 Accepted: November 20, 2014 Online Published: February 12, 2015

doi:10.5539/ass.v11n5p65 URL: http://dx.doi.org/10.5539/ass.v11n5p65

\begin{abstract}
Risk gives the source for opportunity. The concepts of risk and exposure have insignificant differences in their meaning. Risk refers to the probability of loss while exposure is the possibility of loss, though they are habitually used interchangeably. The risk matrix explains that the risk analysis in which rows show the risks and columns show their probability of occurrence and their impact. Financial risk and operational risk occur through countless transactions of a financial and operational nature, including sales and purchases, investments and loans, and various other trade activities. The sample size taken for the study was 230 and the data was collected by way of questionnaire. The study was taken with an objective of analyzing the factors causing financial and operational risk and to examine the protective measures available for such exposures. The findings of the study were to suggest the steps to minimize the financial risk and control the operational risk.
\end{abstract}

Keywords: credit card risk, operational risk, financial risk, credit card grievances

\section{Introduction}

Financial markets are becoming increasingly sophisticated in pricing, isolating, repackaging, and transferring risks. The meaning of risk is discussed in different context but every theory defines risk as the variability of return or income, the chance of nonpayment of debt, the probability of occurrence. A probability or threat of a damage, injury, liability, loss, or other negative occurrence that is caused by external or internal vulnerabilities, and that may be neutralized through preemptive action. Risk provides the basis for opportunity. In this paper we have analyzed only two types of risk: financial risk and operational risk of the customer's point of view to analyze the risk portfolio of the credit card users. The risk matrix explains that the risk analysis in which rows show the risks and columns show their probability of occurrence and their impact. Operational risk, however defined as any risk that is not categorized as market or credit risk, is the risk of loss arising from insufficient or failed internal processes, people and systems or from external events. In order to alleviate this, internal control and internal audit systems are used as the key means. Risk education for disseminate the complex operations at all levels of staff can also diminish operational risk. The recent survey (Excerpts from Final Report of the IIF Committee on Market Best Practices: Principles of Conduct and Best Practice Recommendations) gives us the fact that the usage of credit card is less comparing to the debit card usage. Now the need had emerged to take up a study relating to the awareness and acceptance of degree of risk present in the usage of the plastic money. One thing the card users must keep in mind is that the banks/ financial institutions them as a "sale target". Banks will flatter the card users by calling them as 'valued customer' but in reality the user is simply a potential cash cow. The customers are classified as a 'revolver' (potential cash cow) borrows heavily and regularly, and make only the required minimum payments and never ever makes full payment. Card issuing banks imposes the penalties, fees, service charges when withdrawing cash, paying late, exceeding the credit limit, asking for duplicate receipts, statements etc.

\section{Review of Literature}

$>$ Not only is the plastic money in circulation in India declining, it is also underutilized. On an average, the annual number of transactions per credit cards stands at 11 ; it is only one in case of debit cards. "Debit cards 
have had a slow start and their growth only took off in the last three years. On the other hand, credit cards grew faster since inception, with the growth turning negative in the latest year,"

$>$ There is security risk in using credit card. This type of risk is experienced around the world. For example: The most common type of credit card fraud stems from lost or stolen cards or card numbers, which can lead to the thief using the card or card number for criminal purposes over the telephone or the Internet (card-not present purchases). "skimming," account number generation, hacking, Card Verification Value (CVV), a three-to-four digit number that is printed (not embossed) on the back or front of all US issued credit cards. A newer type of credit card fraud, called "phishing," occurs when a victim is solicited via e-mail to visit a sham website of a "trusted institution" to "confirm or renew" private account information. (MASTERCARD INTERNATIONAL SECURITY \& RISK MANAGEMENT:CREDIT CARD FRAUD Michael Cornish Kathleen Delpha Mary Erslon Credit 2010)

$>$ As regards financial risk, changes in charges (other than interest) may be made only with prospective effect giving notice of at least one month. If a credit card holder desires to surrender his credit card on account of any change in credit card charges to his disadvantage, he may be permitted to do so without the bank levying any extra charge for such closure. Any request for a closure of a credit card has to be honored immediately by the credit card issuer, subject to full settlement of dues by the cardholder. (www.rbi.org.in July 1, 2009 Master circular no.DBOD.FSD.BC.6/24.01.011/2008-09)

$>$ Many banks, making risk "everyone's business" represents a significant shift in mindset, policies, systems and processes, and involves a long-term commitment and investment. More than $70 \%$ of interviewees indicated they are making progress in their efforts to institutionalize an appropriate risk culture throughout the organization. At the same time, only $23 \%$ believe they are close to the end of the process. (Ernst \& Young 2009 IIF report)

$>$ Banks must develop a framework - led jointly by risk and finance — that integrates liquidity risk management with market, credit and operational risk management, as well as economic and regulatory capital management. This will entail day-to-day involvement from the CRO in liquidity management, including defining stress-testing approaches and assumptions. (Peter Marshall is a principal in the Financial Services Office of Ernst \& Young LLP. June 23, 2010)

$>$ R.B.1 Guidelines for Risk Management system in banks" (2009) broadly cover management of credit, market and operational risks. According to the guidelines, the management of credit risk should receive the prime attention of the top management.(rbi.org)

> 2009, US President Barack Obamma signed a new bill into law to curb the most controversial credit card practices, including interest rates hikes, penalties and marketing to college students. (Credit Card Accountability, Responsibility and Disclosure Act of 2009)

$>$ The paper investigates the relationship between the two major sources of bank default risk: liquidity risk and credit risk. The researcher had studied US commercial banks during the period 1998-2010 to analyze the relationship between these two risk sources on the bank institutional-level and how this relationship influences banks' probabilities of default (PD). Both risks separately increase the PD; the influence of their interaction depends on the overall level of bank risk and can either aggravate or mitigate default risk.

$>$ We examine how the banking sector could ignite the formation of asset price bubbles when there is access to abundant liquidity. Inside banks, to induce effort, loan officers are compensated based on the volume of loans. Volume-based compensation also induces greater risk taking; however, due to lack of commitment, loan officers are penalized ex post only if banks suffer a high enough liquidity shortfall.

$>$ The paper on credit risk measurement had given a new approach which can be built around a mortality risk framework to measure the risk and returns on loans and bonds are presented. This model is shown to offer a methodology in analyzing the risk-return structures of portfolios of credit-risk exposed debt instruments.

\section{Research Design}

The credit card is the best source of liquid cash to meet the emergency needs and to meet out the requirements of the individuals when it's used with the proper channel and understanding, it will fetch the best benefit to both the user and the issuer. The reason for choosing the risk analysis of the credit card is to find out the level of awareness of the risk.

\section{Objective of the Study}

1. To analyze the factors causing the financial risk and operational risk.

2. To examine the protective measures existing to manage the risk exposure of credit card users.

The study was undertaken during February - March 2013. The primary data was collected by distributing questionnaire among the teaching faculties using credit cards, those who are from different departments of 
various private Universities, Tamilnadu, India and the corporate employees located in Chennai. The sample size is 230. Research design proposed for the study is 'Descriptive' type of research service. This type of research deals with quality of responses from the respondents, attitudes, interests, technical skills, experience, behavioral, beliefs and values, emotions, personality, self concept etc. Primary data was collected by questionnaire survey method based on a pilot study. Secondary data was collected from journals and Research articles to support the research. The statistical tools used to analyze the financial risk and operational risk are Multiple Regression, $\mathrm{T}$ test, Frequency table.

\section{Results and Discussions}

Multiple Regressions: the multiple regression models was fitted to identify the factors influencing financial risk.

$$
\begin{aligned}
& \text { YFR }=1.064-0.036 \mathrm{nsNtrtc}-0.189 \mathrm{~ns} \text { dutt- } 0.320 \mathrm{~ns} \text { rhat }+0.325 \mathrm{~ns} \text { sowaf }+0.089 \mathrm{nsfftc}+0.996^{*} \text { phlca }+ \\
& \begin{array}{lllll}
(-0.200) & (-0.696) \quad(-1.501) \quad(1.521) \quad(0.842) \quad(4.827)
\end{array} \\
& 0.476 * \text { pdud }-0.593 * \text { trebi }+0.636 * \text { paduda }+0.337 * \text { painadv }+1.781 * \text { noaprpa }+1.021 * \text { fifday }+0.766 * \text { forday } \\
& \begin{array}{llllll}
(2.973) & (-3.501) & (2.678) & (4.923) & \text { (8.352) }
\end{array} \\
& +0.244 \text { nsthirday }+0.770 * \text { twenday }+1.826 * \text { anytime }+0.452 * \text { mino } / \mathrm{s}-1.808 * \text { payful }+0.636 * \text { payonwhexca } \\
& \begin{array}{lllll}
(1.177) \quad(3.728) \quad(8.705) & (2.609) & (-9.112)
\end{array}
\end{aligned}
$$
(4.867)
$(0.877)$
(4.304)
(2.074)
(3.211)

\section{* Significant at 5\% level ns - Not significant Figures in ( ) - $t$ values}

Interpretation: Multiple regressions were fitted to identify the determinants of Financial risk. The regression was fitted with Financial risk as the dependent variable and No time to read terms and condition, do not understand the terms \& conditions, read here and there, only sign where asked for, read fully the terms, period of holding the cards, card payment on due date, payment on receipt of bill, payment in advance, not a prompt payer, fifty days period, forty days period, thirty days period, twenty days period, anytime, minimum outstanding, pay fully, pay only when excess cash flow, not prompt and regular, when bank forces me, interest rate charged, awareness of charges, interest rate charged, interest rate on late fee, services charges on grace period allowed, interest on cash withdrawal, no such extra charges and the charges on daily basis were considered as independent variable. The equation fitted indicated an R2 value implying that more than $96 \%$ of variation in financial risk is explained by the independent factors included for the analysis. The F(170.0) value implied that R2 (0.960) is statistically significant and so the equation is fit for interpretation.

From the equation we notice that period of holding the credit card is a significant factor influencing the financial risk. For every unit increase in the period the financial risk would go up by 0.996 units. The credit card payments made on the due dates is a significant factor influencing the financial risk, for every delay in payment on the due date the financial risk would go up by 0.476 units. If the customer pays immediately on the receipt of the bill the risk will go down by -0.593 . When the customers pay the bill after due date the financial risk level significantly go up by 0.636 . When the payment is made well in advance the risk level is minimal to 0.337 . When the customers are not prompt and regular in their payment the risk was significantly high at 1.781 for every unit of delay.

Further the equation had revealed that if the card holders' payment duration is fifty days from the date of purchase risk for the period goes up by 1.021 units for every unit of delay, when it is forty days from the date of purchase, the risk level is somewhat less [0.766 units], in case of thirty days the risk level further comes down to 0.244 and if its only twenty days to pay the risk significantly goes up by 0.770 , apart from the various due dates if the option of making the payment on anytime convenient to the customer the financial risk hikes up to 1.826 which means the cardholders end up paying extra charges which will in turn increase their degree of financial risk. The customers prefer to make the minimum payment outstanding due for the particular month they are exposed to the financial risk by 0.452 units, when the customer pays the bills outstanding fully and clear every month the risk is very meager (-1.808 unit). The customers who pay whenever they have excess cash flow the financial risk increases to 0.636 unit, the customers who are not prompt and regular payer will have a risk level of 1.442 units. The interest rates charged by the credit card issuers on the usage value significantly increase the financial risk by 0.805 units. The level of awareness of the various charges imposed on the credit cards had shown a higher degree of financial risk [1.014]. 
The equation had explained that the every unit increase in the interest rates charges on the late fee would increase the risk by 0.664 units. The risk level is 1.445 units when the interest rate is charged on the grace period allowed for payment; it's evident that the increase in grace period will increase the financial risk of the user. The interest rate charges on the cash withdrawal increases the financial risk of the user by 0.303 units. The customers who are not at all aware of the charges collected by the issuing authority on the usage of credit cards the risk is at 0.143 unit, which appears to be less because the responses to the questions are based on the lack of understanding of the consequence of unawareness about the charges being collected. Since the charges are imposed on the basis of daily outstanding balance, for every day of delay in payment the financial risk would go up by 0.943 units. Thus its concluded that the payment of the credit card should be made on the due date prescribed by the issuing banks so as to minimize the financial risk.

The Multiple Regression was fitted to identify the factors influencing operational risk.

$$
\begin{aligned}
& \text { YOR }=0.157+1.842 * \text { disexch }+1.429 * \text { diswrac }+1.349 * \text { misopr- } 1.389 * \text { nodisp- } 1.545 * \text { nodebi }+1.396 * \text { smsale } \\
& \begin{array}{llllll}
(20.371) & (18.456) & (15.685) & (22.140) & \text { (22.282) }
\end{array} \\
& +1.319 * \text { olibl }+1.619 * \text { sotide }+1.671 * \text { nprocomm }-0.991 * \text { ratebredo }+1.524 * \text { veroft }+1.130 * \text { somtim }+1.406 * \text { feti } \\
& \begin{array}{llllll}
(16.449) & (17.505) & (20.156) & (13.433) & (15.156) & (11.522)
\end{array}
\end{aligned}
$$

$-1.177 *$ noall

$(16.942)$

$\mathrm{R} 2=0.993, \mathrm{~F}=2324.529$

Interpretation: Multiple regressions was fitted to identify the determinants of Operational risk. The regression was fitted with Operational risk as the dependent variable and dispute on excess charges, dispute on wrong account, dispute on mistake in print, no disputes, no delay in bill, sms alert, online billing, sometimes delay, no proper communication, very rare technology breakdown, sometimes, few times, not at all were considered as independent variable. The equation fitted indicated an R2 value indicated that more than $99 \%$ of variation in operational risk is explained by the independent factors included for the analysis. The F value (2324.529) implied that R2 (0.993) is statistically significant and so the equation is fit for interpretation. From the equation we notice that the disputes arising out of excess charges imposed wrongly increases the risk of the user by 1.842 units, issues of wrong accounting hikes the operational risk by 1.429 units, the clerical errors like typing and printing mistakes increases the operational risk by 1.349 units which directly influences the consequences of financial risk. When there is no dispute the risk is minimum (-1.389units), when there is no delay in receipt of the bill again the risk is minimum (-1.545units) which means the users are not exposed to any risk. The sms alert send by the issuer is not considered by the user the degree of risk increases by 1.396 units. The credit card users transacting and communicating with the issuing bank only through online and they receive all type of communications and bills online which shows the degree of operational risk as 1.319 units. The bill sent sometimes delayed the risk goes up by 1.619 units. When the credit card users are not getting proper communication or no communication from the issuing banks the operational risk increases highly by 1.671 units.

The credit card users face the technology breakdown rarely while processing their transaction the risk is minimum (-0.991unit). The credit card users facing the technology breakdown is the prime cause of operational risk which only a certain percentage of card holders are aware, the degree of risk involved for the users who very often face this problem is higher by 1.524 units. The risk increases by 1.130 and 1.406 units when the users face it sometimes and few times. When there is no such technology problem the operational risk faced by the card holders are very meager (-1.177 units). Thus it's evident from the study that the credit cards holders are exposed to the operational risk which if not noticed and corrected will lead to the other type risk which will end up with customer bankruptcy. The factors like communication gap and the technology breakdown to be immediately corrected to always have control on the operational risk.

\section{Suggestions}

* The $70 \%$ of the respondents are not aware of the grievances cell and its operation to protect their loss. The credit card users are suggested to read all the clauses printed in small fonts in the credit card agreement to understand the terms and the protective measures applicable for the customer.

* $52 \%$ of the respondents had revealed that they don't have awareness of the various protective measures given by the banks, the customers expect to have explanation to understand the measures and the procedures to protect themselves from the operational and security risk.

* If the cards is stolen, misused, malpractice immediately report to the issuing authority and cooperate to provide all details required to help you minimize your risk. 
* The customers must be aware of the pitfalls of extra credit card charges, the cardholder must every time ask for the explanation and the breakups for the charges charged to know and understand the real usage of the plastic money.

* It's suggested that the issuing authority should take a step ahead to explain the terms and conditions and the protective measures available to them so as to minimize the financial and operational risk at both levels.

\section{Conclusion}

The theories and literature had proven that the credit card issuing banks are ready for the risk appetite and finding the strategies to change and digest the risk of factors identified. The central banks in the global economies had straightened the rules and regulations relating to the issue and the usage of the credit cards for issuing authorities and for customers. The time has come were the customers need to know the degree of risk involved in the usage of plastic money, and the study had helped to identify the factors and the degree of risk exposed and the protective measures available to minimize the financial and operational risk. It's clear from the study that the awareness of the customer is comparatively less and the credit card issuing banks are processing a strategy to educate the users of credit card.

\section{References}

Acharya, V., \& Naqvi, H. (2012). The seeds of a crisis: A theory of bank liquidity and risk taking over the business cycle. Journal of Financial Economics, 106(2), 349-366. http://dx.doi.org/10.1016/j.jfineco.2012. 05.014

Acharya, V. V., \& Mora, N. (2013). A crisis of banks as liquidity providers. Journal of Finance.

Altman, E. I., \& Saunders, (1997). A. Credit risk measurement: Developments over the last 20 years. Journal of Banking and Finance, 21(11-12), 1721-1742. http://dx.doi.org/10.1016/S0378-4266(97)00036-8

Ashish, das, Agarwal, R. (2010). Cashless payment system in India- A roadmap. Technical report

Biggs, M., Mayer, T., \& Pick, A. (2009). Credit and economic recovery. De Nederlandsche Bank Working Paper, no. 218 .

Brimmer, A. F. (1998). Bank lending and the Asian economic crisis. The North American Journal of Economics and Finance, 9, 105-119. http://dx.doi.org/10.1016/S1062-9408(99)80083-7

Carow, K. A., \& Staten, M. E. (1999). Debit, credit, or cash: Survey evidence on gasoline purchases. Journal of Economics and Business, 51, 210-224. http://dx.doi.org/10.1016/S0148-6195(99)00016-8

Durkin, T. A. (2000). Credit cards: Use and consumer attitudes 1970-2000. Federal Reserve Bulletin, 86, 623-634.

Ernst \& Young. (2009). IIF report.

Feinberg, R. A. (1986). Credit card as spending facilitating stimuli: A conditioning interpretation. Journal of Consumer Research, 13, 348-356. http://dx.doi.org/10.1086/209074

Imbierowicz, B., \& Rauch, C. (2014). The relationship between liquidity risk and credit risk in banks. Journal of Banking and Finance, 40(1), 242-256. http://dx.doi.org/10.1016/j.jbankfin.2013.11.030

King, A. S., \& King, J. T. (2005). The decision between debit and credit: Finance charges, float, and fear. Financial Services Review, 14, 21-36.

Michael Cornish Kathleen Delpha Mary Erslon Credit 2010. Mastercard International Security \& Risk Management: Credit Card Fraud; A Report on Global Fraud Management Overview.

www.rbi.org. in July 1, 2009 Master circular no.DBOD.FSD.BC.6/24.01.011/2008-09.

Zimman, J. (2009). Debit or credit? Journal of banking\& finance, 33(2), 358-366. http://dx.doi.org/10.1016/ j.jbankfin.2008.08.009

\section{Copyrights}

Copyright for this article is retained by the author(s), with first publication rights granted to the journal.

This is an open-access article distributed under the terms and conditions of the Creative Commons Attribution license (http://creativecommons.org/licenses/by/3.0/). 